\title{
MASA KERJA, TINGKAT PENDIDIKAN, DAN ROTASI KERJA MENINGKATKAN KINERJA PERAWAT Di RS JIWA Dr. SOEHARTO HEERDJAN
}

\author{
SURYANI MARYAM
}

Fakultas Ilmu Ilmu Kesehatan, Universitas Pembangunan Nasional "Veteran” Jakarta, Jakarta Selatan, 12450, Indonesia

\begin{abstract}
Abstrak
Penelitian ini bertujuan untuk menganalisa hubungan masa kerja, tingkat pendidikan, dan rotasi kerja terhadap kinerja Perawat di RS Jiwa; serta variabel manakah yang paling penting hubungannya terhadap kinerja perawat di rumah sakit tersebut. Pengambilan sampel dilakukan di RS Jiwa secara purposive sampling sebanyak 114 perawat. Teknik pengumpulan data menggunakan survey data primer dan sekunder. Data dianalisis dengan menggunakan uji normalitas, multikolinearitas, heteroskedastisitas, dan regresi berganda . Hasil penelitian menunjukkan terdapat hubungan yang sangat signifikan dari variabel masa kerja; variabel tingkat pendidikan dan variabel dummy rotasi kerja terhadap kinerja dimana masing-masing nilai probabilitas (sig) bernilai 0,000 . Nilai beta coefficient dalam penelitian ini paling tinggi pada variabel masa kerja sebesar 0,622. Kesimpulan penelitian ini adalah semakin tinggi tingkat pendidikan, semakin lama seorang perawat bekerja dan rotasi kerja dapat meningkatkan kinerja perawat di RS Jiwa Dr. Soeharto Heerdjan. Variabel yang paling penting hubungannya terhadap kinerja perawat yaitu masa kerja.
\end{abstract}

Kata kunci : Masa kerja, Tingkat Pendidikan, Rotasi Kerja dan Kinerja

\section{ABSTRACT}

\section{Period of work, Education Level, and Job Rotation to the Performance of nurses at Mental Hospital}

This research aimed to analyze the correlation among period of work, level of education, and job rotation to the performance of nurses working in Mental Hospital as well as a variable which is the most important influence on the performance of nurses at the hospital. Sampling was done at the Mental Hospital by purposive sampling of 114 nurses. Survey data collection techniques using primary and secondary data. Data were analyzed using tests of normality, multicollinearity, heteroscedasticity, and multiple regression. The result showed that there are very significant correlation of the variable period of work, variables on the education levels, and dummy variables for job rotation on the performance in which each probability value (sig) worth 0.000 . Beta coefficient values in this research are highest at 0.622 for a variable period of work. Conclusions of this research is the higher level of education, the longer a nurse work and job rotation can improve the performance of nurses at Mental Hospital. The most important variables correlates toward performance of nurses is period of work.

Key Words: Period of work, Education Level, Job Rotation and Performance 


\section{PENDAHULUAN}

Era Globalisasi merupakan era baru yang akan membawa berbagai perubahan di bidang kehidupan. Salah satunya yaitu perubahan di bidang kesehatan. Terbuktinya pasar bebas akan berakibat pada tingginya kompetisi di bidang kesehatan dalam memberikan pelayanan kesehatan.

Mutu Pelayanan kesehatan di rumah sakit sangat dipengaruhi oleh kualitas sarana fisik, jenis tenaga yang tersedia, obat dan alat kesehatan serta proses pemberian pelayanan. Oleh karena itu, peningkatan mutu faktorfaktor tersebut termasuk sumber daya manusia dan profesionalisme diperbolehkan agar pelayanan kesehatan yang bermutu dan pemerataan pelayanan kesehatan dapat dinikmati oleh seluruh lapisan masyarakat.

Pelayanan keperawatan merupakan bagian integral dari sistem pelayanan kesehatan, sehingga mutu pelayanan kesehatan juga ditentukan oleh mutu pelayanan keperawatan. Sehubungan dengan hal tersebut, pelayanan keperawatan harus dikelola secara professional sehingga dapat memberikan kontribusi terhadap citra rumah sakit melalui pemberian asuhan keperawatan yang paripurna. Hal ini menuntut adanya peningkatan kualitas serta profesionalisme sumber daya manusia kesehatan termasuk juga didalamnya sumber daya manusia keperawatan agar mampu bersaing.

Perawat merupakan salah satu tenaga kesehatan yang memiliki frekuensi interaksi paling tinggi dengan pasien dalam memberikan pelayanan kesehatan dibandingkan dengan petugas kesehatan lainnya sehingga sering dijadikan ukuran satu-satunya profesi kesehatan di rumah sakit yang banyak memberikan persepsi terhadap pelayanan kesehatan pada diri pasien.
Pada semua pengaturan klinik, perawatperawat bekerja dengan orang yang akan mengalami krisis, termasuk fisik, psikologis, mental dan spiritual. Perawat akan menemukan pasien-pasien yang mengalami keputusasaan, tak berdaya, cemas, marah, harga diri yang rendah dan kebingungan. Perawat juga akan menemui pasien-pasien yang menarik diri, curiga, gembira, depresi, ingin bunuh diri, dan perilaku kekerasan. Perawat harus mampu menangani situasisituasi ini dengan terampil, tetapi pada waktu lain perawat diharapkan memiliki keterampilan tambahan dan pengetahuan.

Tekanan ekonomi, globalisasi dan kemiskinan dapat memicu meningkatnya penderita gangguan jiwa. Dari survei kesehatan daerah tentang gangguan jiwa mental dan emosional oleh Kementerian Kesehatan, jumlah penderita gangguan jiwa di Jakarta mencapai angka 14,1 persen dari jumlah penduduk. Jumlah itu di atas angka nasional sebesar 11,6 persen, sebagaimana tercantum dalam websitekompas.com pada tanggal 11 Oktober 2011.

Kepala Dinas Kesehatan DKI Jakarta Dien Emawati, mengatakan bahwa jumlah penderita gangguan jiwa ringan hingga triwulan kedua tahun 2011 telah mencapai angka 306.621 orang. Jika dibandingkan dengan kasus yang sama pada tahun 2010 tercatat jumlah penderita sakit jiwa sebanyak 150.029 orang, ini berarti terjadi pertumbuhan penderita sakit jiwa di DKI hingga $100 \%$, sedangkan di dunia 450 juta orang mengalami gangguan jiwa. Dari data tersebut, perlu disiapkan rumah sakit jiwa yang mampu menangani pasien-pasien gangguan jiwa dengan baik melalui peningkatan mutu sumber daya manusianya, termasuk perawat. Salah satu tujuan rumah sakit adalah tercapainya indikator kinerja pelayanan rumah sakit. 
Di sebagian besar organisasi, kinerja para karyawan individual merupakan faktor utama yang menentukan keberhasilan organisasi. Banyak faktor yang mempengaruhi kinerja karyawan individual-kemampuannya, usaha yang dicurahkan, dan dukungan organisasi yang diterimanya. Kinerja RS Jiwa sangat ditentukan oleh kinerja sumber daya manusianya.

Perawat yang paling memegang peranan penting dalam menentukan kinerja rumah sakit karena mereka merupakan sumber daya manusia yang paling banyak. Perawat juga yang paling sering kontak dengan pasien dan keluarganya untuk kesembuhan pasien. Oleh karena itu diperlukan sumber daya perawat yang berkualitas.

Hasil wawancara dengan beberapa kepala ruangan di Rumah Sakit JIwa Dr. Soeharto Heerdjan diketahui bahwa perawat pelaksana sudah cukup baik dalam melakukan pengkajian namun masih ada perawat yang belum mampu menggali masalah pasien secara mendetil. Masalah tersebut terjadi karena kurangnya pengetahuan tentang cara melakukan pengkajian yang lengkap, kurangnya pengalaman dalam menghadapi pasien gangguan jiwa sehingga pengkajian kurang maksimal. Pengalaman dalam memberikan asuhan keperawatan kepada pasien gangguan jiwa sangat berharga untuk pembelajaran perawat dalam menangani pasien.

Hasil wawancara kepada beberapa perawat diketahui bahwa pelatihan jarang diberikan kepada perawat sementara pelatihan sangat dibutuhkan untuk meningkatkan keterampilan mereka. Selain itu, jenis kunjungan lebih banyak pasien lama. Data dari Instalasi Rekam Medis tahun 2010 yang penulis dapatkan diketahui bahwa kunjungan pasien baru di Rumah Sakit Jiwa Dr. Soeharto Heerdjan hanya 4\% sedangkan kunjungan pasien lama 96\%. Hal ini mempunyai dampak kejenuhan pada perawat apabila mereka merawat pasien yang sama dalam waktu lama di ruang rawat yang sama. Kejenuhan ini bisa berdampak pada penurunan kinerja perawat. Pada tahun1990-an seluruh perawat dirotasi untuk mengurangi kejenuhan, namun sejak tahun 2010 tidak semua perawat dirotasi.

Data dari profil RS Jiwa menunjukkan mayoritas tingkat pendidikan perawat adalah Diploma 3. Pihak rumah sakit memberikan kesempatan kepada perawat yang berpendidikan Sekolah Pendidikan Keperawatan (SPK) atau D3 keperawatan untuk melanjutkan pendidikan S1 Keperawatan dengan profesi keperawatan (S.Kep, Ners). Namun adanya kendala biaya yang cukup mahal dan waktu, masih sedikit perawat yang lulusan S1 Keperawatan.

Berkenaan dengan permasalahan di atas, maka penulis tertarik untuk melakukan penelitian tentang pengaruh masa kerja, pendidikan, dan rotasi kerja terhadap kinerja perawat di RS Jiwa Dr. Soeharto Heerdjan. Selain itu penulis ingin mengetahui faktor yang paling dominan di antara ketiga faktor tersebut yang mempengaruhi kinerja perawat.

\section{RUMUSAN MASALAH}

Berdasarkan batasan masalah penelitian, maka rumusan masalah akan melihat apakah ada hubungan antara tingkat pendidikan, masa kerja dan rotasi kerja terhadap kinerja perawat RS. JIwa Dr. Soeharto Heerdjan. Rumusan masalah tersebut adalah : 
1. Apakah terdapat pengaruh masa kerja, tingkat pendidikan dan rotasi kerja secara parsial maupun simultan terhadap kinerja perawat di RS Jiwa Dr. Soeharto Heerdjan?

2. Variabel manakah yang paling dominan dari masa kerja, tingkat pendidikan dan rotasi kerja mempengaruhi kinerja perawat RS Jiwa Dr. Soeharto Heerdjan?

\section{TUJUAN PENELITIAN}

Sesuai dengan perumusan masalah, maka tujuan penelitian ini sebagai berikut:

1. Menganalisis pengaruh masa kerja, tingkat pendidikan, dan rotasi kerja secara parsial terhadap kinerja Perawat RS. Jiwa Dr. Soeharto Heerdjan.

2. Menganalisis tingkat pentingnya variabel masa kerja, tingkat pendidikan, dan rotasi kerja dalam mempengaruhi kinerja Perawat RS. Jiwa Dr. Soeharto Heerdjan.

\section{METODE PENELITIAN}

\section{A. Desain Penelitian}

Penelitian ini menggunakan desain deskriptif analitik. Dalam penelitian ini desain penelitian deskriptif bertujuan untuk memberikan gambaran mengenai variabel independent yaitu masa kerja (X1), tingkat pendidikan (X2) dan rotasi kerja (D) dan variabel dependent yaitu kinerja perawat RS Jiwa $\mathrm{X}$.

Desain penelitian analitik ini bertujuan untuk menguji hipotesis mengenai pengaruh masa kerja perawat (X1), tingkat pendidikan (X2), rotasi kerja (D) terhadap kinerja perawat (Y) di RS
Jiwa Dr. Soeharto Heerdjan. Melalui desain penelitian analitik akan diperoleh tingkat signifikansi dari pengaruh antara masa kerja perawat (X1), tingkat pendidikan (X2), rotasi kerja (D) sebagai variabel independent terhadap kinerja sebagai variabel dependent melalui uji regresi dengan menggunakan program SPSS versi 19.0 .

\section{B. Waktu dan Tempat Penelitian}

Penelitian ini dilakukan di Rumah Sakit Jiwa Dr. Soeharto Heerdjan, J1. Prof. DR. Latumenten no.1, Jakarta Barat. Kegiatan pengumpulan dan pencarian data penelitian yang terkait dengan variabel dependen dan independen pada penelitian ini dilakukan di ruang Pendidikan dan Pelatihan serta ruangruang rawat inap dewasa, anak dan remaja. Pra penelitian dilakukan penulis pada Oktober 2011 dan pengambilan data-data dilakukan pada bulan November hingga Desember 2011.

\section{Teknik Pengumpulan Data dan Pengambilan Sampel}

Penelitian ini menggunakan data primer dan sekunder. Data primer didapatkan dari pengisian kuesioner penilaian kinerja yang dilakukan oleh seluruh kepala ruang rawat inap anak, dewasa dan rehabilitasi.

Data sekunder penulis peroleh dari RS Jiwa Dr. Soeharto Heerdjan yang sebelumnya telah diolah terlebih dahulu oleh departemen terkait di RS Jiwa Dr. Soeharto Heerdjan

\section{Populasi dan Sampel}


Populasi penelitian ini adalah seluruh perawat RS Jiwa Dr. Soeharto Heerdjan yang berjumlah 162 orang yang terdiri dari staf perawat sebesar 15 orang, pegawai di bagian struktural sebesar 5 orang, dan sisanya perawat fungsional sebesar 142 perawat. Sampel untuk penelitian ini diambil sebanyak 114 orang perawat pelaksana yang bekerja di ruang rawat inap anak dan remaja, dewasa, serta rehabilitasi

\section{E. Teknik Pengumpulan Sampel}

Pada penelitian ini teknik pengumpulan sampel menggunakan metode purposive sampling, dengan kriteria sebagai berikut :

a. Perawat yang telah memiliki Nomor Induk Pegawai (NIP)

b. Perawat pelaksana yang bekerja di ruang rawat inap anak dan remaja, dewasa serta rehabilitasi.

\section{F. METODE ANALISIS}

Penulis menggunakan alat analisis regresi berganda untuk mengetahui apakah terdapat hubungan signifikan antara variabel-variabel independent dengan variabel dependent dan untuk menunjukkan arah dan besaran variabel-variabel dependent dalam penelitian ini

\section{HASIL DAN PEMBAHASAN}

\section{Analisis Deskriptif}

Pada tahap ini dilakukan analisis terhadap responden perawat sebanyak 114 orang yang terdiri dari : $73.68 \%$ adalah wanita sedangkan 26.32\% adalah laki-laki. Perawat yang memiliki pendidikan SPK sebanyak 3 orang
(2,63\%), D3 Keperawatan sebanyak 72 orang $(63,15 \%)$, dan S1 keperawatan sebanyak 39 orang (34.22\%).

Perawat yang memiliki masa kerja selama 1 - 9 tahun yaitu sebanyak 65 orang atau 57.02\%. 10 - 19 tahun sebanyak 25 orang atau $21.93 \%$, perawat dengan masa kerja antara 20 29 tahun sebanyak 20 orang atau $17.54 \%$ dan perawat dengan masa kerja antara $30-37$ tahun sebanyak 4 orang atau $3.51 \%$. Perawat yang dirotasi sebanyak 42 orang atau $36.84 \%$ sedangkan perawat yang tidak dirotasi sebanyak 72 orang atau $63.16 \%$. Dari 42 orang perawat yang dirotasi terdiridari : 11 perawat laki-laki dan 31 perawat wanita.

Berdasarkan hasil analisa data didapatkan nilai kinerja terendah adalah 74.83 dan tertinggi adalah 83.50. Tidak ada perawat yang memiliki nilai kinerja sangat baik maupun kurang baik. Perawat yang memiliki nilai kinerja antara $74-76$ sebanyak 7 orang atau $6.14 \%$. Dalam DP3 nilai ini termasuk kategori cukup baik. Perawat yang memiliki nilai kinerja antara $76-83.50$ sebanyak 107 perawat atau $93.86 \%$. Hal ini menunjukkan bahwa mayoritas perawat RS Jiwa Dr. Soeharto Heerdjan memiliki kinerja yang baik.

Hasil penelitian responden terhadap kinerja perawat mencapai nilai rata-rata terendah pada unsur prestasi yaitu sebesar sebesar 79.27 dan termasuk dalam kategori baik tetapi perlu ditingkatkan untuk menjadi kategori sangat baik. Sedangkan untuk nilai ratarata tertinggi terdapat pada unsur kejujuran yaitu sebesar 79.81 berada dalam kategori baik tetapi perlu 
ditingkatkan hingga menjadi kategori sangat baik.

\section{Hasil Uji Asumsi Klasik}

\section{a. Uji Normalitas}

Hasil Uji Normalitas menunjukkan titik-itik menyebar di sekitar garis diagonal dan penyebarannya mengikuti arah garis diagonal, yang berarti nilai residual berdistribusi normal, sehingga model regresi layak dipakai untuk memprediksi kinerja berdasarkan masukan semua variabel independent.

\section{b. Uji Multikolineritas}

Hasil Uji multikolinearitas diketahui bahwa tidak terdapat nilai korelasi antar variabel bebas yang lebih tinggi dari 0.8 sehingga tidak terjadi multikolinearitas yang serius.

\section{c. Uji Heterokedastisitas}

Hasil uji heterokedastisitas menunjukkan titik-titik menyebar secara acak (random) baik di atas maupun di bawah angka 0 sumbu y dan tidak membentuk suatu pola tertentu yang jelas, serta tersebar secara merata. Hal ini menunjukkan model regresi bebas dari heteroskedastisitas, sehingga model regresi layak dipakai

\section{Analisa Regresi Linier Berganda}

\section{a. F-test (ANOVAb)}

Hasil pengolahan uji ANOVA, didapat nilai $\mathrm{F}$ hitung sebesar 56.450 dengan probabilitas 0.000 . Karena probabilitas $(0.000)$ jauh lebih kecil $(<)$ dari 0.05 , maka model regresi dapat digunakan untuk memprediksi
Kinerja atau dapat dikatakan bahwa Masa Kerja, Pendidikan, dan Rotasi secara bersama-sama (simultan) berpengaruh terhadap Kinerja.

\section{b. R Square (Koefisien Determinasi)}

Model regresi ini mempunyai koefisien determinasi, R2 $=0.606$. Hal ini berarti $60,6 \%$ variasi kinerja diterangkan oleh variabel masa kerja, tingkat pendidikan,dan rotasi kerja; sedangkan sisanya $\quad 39.4 \%$ dideterminasi/ditentukan oleh variabel-variabel lain yang tidak dilibatkan dalam penelitian ini.

\section{c. R (Korelasi Antar Frekwensi)}

Dari hasil perhitungan, didapatkan angka korelasi antar frekwensi (R) sebesar 0.779. Hal ini menggambarkan bahwa variabel independen yaitu: masa kerja, tingkat pendidikan, dan rotasi kerja memiliki hubungan yang kuat dengan kinerja perawat sebagai variable dependen. Korelasi positif menunjukkan bahwa hubungan tersebut searah dengan Kinerja.

\section{d. Uji Signifikansi Individual (Uji statistic t)}

Tabel 1. Nilai Signifikansi Variabel Bebas Terhadap Variabel Terikat di RS Jiwa X

\begin{tabular}{|l|c|c|c|}
\hline Model & $\begin{array}{c}\text { Unstandardi } \\
\text { zed } \\
\text { Coefficient } \\
\mathrm{B}\end{array}$ & $\begin{array}{c}\text { Standard } \\
\text { ized } \\
\text { Coefficie } \\
\mathrm{nt} \\
\mathrm{B}\end{array}$ & Sig \\
\hline Constant & 75.399 & & .000 \\
\hline $\begin{array}{l}\text { Masa } \\
\text { Kerja }\end{array}$ & .161 & .622 & .000 \\
\hline Tingkat & .584 & .233 & .000 \\
\hline
\end{tabular}




\begin{tabular}{|l|l|l|l|}
\hline $\begin{array}{l}\text { Pendidik } \\
\text { an }\end{array}$ & & & \\
\hline $\begin{array}{l}\text { Rotasi } \\
\text { Kerja }\end{array}$ & 1.091 & .231 & .000 \\
\hline
\end{tabular}

Berdasarkan hasil analisis (tabel 1), diketahui bahwa konstanta $=75.399$ dengan nilai $\mathrm{P}=0,000$, maka dapat dikatakan bahwa konstanta tersebut signifikan. Koefisien regresi masa kerja perawat $=0,161$ dengan nilai $\mathrm{P}=0,000$ maka dapat dikatakan bahwa variabel masa kerja perawat berpengaruh sangat signifikan terhadap kinerja perawat.

Tingkat pendidikan memiliki koefisien regresi $=0.584$ dengan nilai $\mathrm{P}=0,000$ maka dapat dikatakan bahwa variabel tingkat pendidikan berpengaruh sangat signifikan terhadap kinerja perawat.

Rotasi kerja dengan koefisien regresi $=$ 1.091 dengan nilai $\mathrm{P}=0,000$ maka dapat dikatakan bahwa penerapan rotasi kerja berpengaruh sangat signifikan terhadap kinerja perawat.

Kesimpulannya tingkat signifikansi koefisien korelasi ketiga variabel bebas di atas menghasilkan angka 0.000, maka variabel masa kerja, tingkat pendidikan dan rotasi kerja secara signifikan (sig._5\%) berpengaruh terhadap kinerja.

\section{e. Analisis Beta Coefficient}

Untuk menganalisis variabel independen yang paling dominan mempengaruhi kinerja perawat, peneliti menggunakan Beta Coefficient dalam regresi berganda. Beta Coefficient (harga mutlak Beta) pada tabel menunjukkan bahwa masa kerja adalah variabel yang paling dominan mempengaruhi kinerja perawat, kemudian diikuti secara berurutan oleh variabel tingkat pendidikan dan rotasi kerja.

\section{f. Persamaan Regresi (Beta Coefficients Unstandardized)}

Setelah melihat hasil analisis regresi berganda pada tabel 4.7, maka model persamaan regresinya sebagai berikut :

$$
\mathrm{Y}=75.399+0.161 \mathrm{X} 1+0.584
$$

$\mathrm{X} 2+1.091 \mathrm{D} 1$

Dengan angka + (plus) pada konstanta pada tabel B Unstandardized Coefficients, menunjukkan bahwa bila ada penambahan pada variabel independen (Masa Kerja, Pendidikan, dan Kinerja), maka akan mengakibatkan penambahan pada variabel dependen (Kinerja) atau Kinerja sangat dipengaruhi oleh masa kerja, pendidikan, dan rotasi kerja. Nilai konstanta sebesar 75.399 menunjukkan nilai variabel kinerja tanpa dipengaruhi variabel masa kerja, tingkat pendidikan, dan Rotasi Kerja.

\section{PEMBAHASAN}

Hasil persamaan regresi terlihat bahwa Masa Kerja (X.1) dengan nilai probabilitas (Sig) 0.000 yang berarti sigrifikan karena $<$ dari 0.005. Hal ini menunjukkan bahwa terdapat kontribusi positif yang dihasilkan variabel Masa Kerja. Koefisien regregi X1 sebesar 0.161 menyatakan bahwa setiap penambahan (karena tanda + ) sebesar 1 angka masa kerja akan meningkatkan kinerja sebesar 0.161 .

Hasil persamaan regresi terlihat bahwa Pendidikan (X2) 0.584 dengan nilai probabilitas (Sig) 0.000 yang berarti signifikan karena $<$ dari 0.005 . Hal 
inimenunjukkan bahwa terdapat kontribusi positif yang dihasilkan variabel pendidikan, yaitu jika Pendidikan naik sebesar 1 angka, maka akan diikuti oleh peningkatan Kinerja sebesar 0.585 .

Hasil persamaan regresi terlihat bahwa variabel dummy rotasi (X3) 1.091 dengan nilai probabilitas (Sig) 0.000 yang berarti signifikan karena kurang dari 0.005. Hal ini menunjutkan bahwa terdapat kontribusi positif yang dihasilkan variabel dummy rotasi yaitu jika rotasi kerja dilakukan maka akan memperoleh peningkatan kinerja lebih tinggi sebesar 1.091 daripada perawat yang tidak dilakukan rotasi.

Berdasarkan pembahasan secara deskriptif maka diketahui rata-rata kinerja perawat ruang rawat inap di Rumah Sakit Jiwa X baik. Semakin lama perawat bekerja di suatu rumah sakit maka semakin baik kinerja yang dihasilkan. Hal ini sejalan dengan teori yang dikemukakan oleh Mangkuprawira yang telah dikemukakan pada bab terdahulu menyatakan bahwa dari bahwa dari pengalaman kerja seseorang memperoleh pembelajaran untuk berperilaku yang lebih baik sehingga pengalaman kerja merupakan kondisi yang digunakan oleh seseorang didalam proses umpan balik untuk meningkatkan mutu perencanaan, pelaksanaan hasil pekerjaannya. Hal ini juga sejalan dengan Teori Ivancevich, J, M yang menyatakan bahwa pengalaman kerja yang lalu dari seorang karyawan pada pekerjaan yang sama merupakan salah satu indikator yang baik untuk kinerja yang akan datang.

Pengalaman perawat dalam melakukan tindakan-tindakan medis seperti memasang infus, selang kateter, selang nasogastrik, merawat luka, menyuntik, dan sebagainya membuat perawat menjadi terampil. Begitu pula, pengalaman perawat yang lama dalam menangani pasien-pasien dengan gangguan jiwa menjadi pembelajaran yang berharga untuk dirinya sendiri maupun dalam menangani pasien-pasien gangguan jiwa.

Penelitian ini diperkuat oleh penelitian sebelumnya yang dilakukan oleh Ratna (2011) yang menyatakan bahwa pendidikan dan masa kerja memiliki pengaruh yang signifikan terhadap kinerja karyawan

Berdasarkan tabel 1.1 menunjukkan bahwa pendidikan mempunyai pengaruh yang signifikan terhadap kinerja perawat. Hal ini sejalan dengan teori Mangkuprawira pada bab terdahulu yang menyatakan bahwa Semakin tinggi penguasaan derajat intelektualitasnya, maka semakin terbuka kemampuaannya untuk meningkatkan produktivitas kerjanya.

Semakin tinggi pendidikan perawat, kemungkinan daya analisa dalam menangani masalah keperawatan maupun medis semakin tinggi sehingga penerapan asuhan keperawatan kepada pasien semakin baik. Hasil ini diperkuat juga dari penelitian Sumarno (2007) yang menyatakan bahwa pendidikan memiliki pengaruh signifikan terhadap kinerja karyawan.

Hasil penelitian ini juga menunjukkan bahwa perawat yang dilakukan rotasi kerja memiliki kinerja lebih tinggi dibandingkan perawat yang tidak dirotasi. Hal ini sejalan dengan teori yang dikemukakan oleh Varcolis, E. M dan Halter, M, J (2010) yang menyatakan bahwa pengalaman perawat dalam rotasi keperawatan jiwa membantu perawat mendapatkan wawasan tentang diri sendiri dan juga meningkatkan wawasan perawat ke dalam pengalaman orang lain. Begitu pula dengan teori Sjafri Mangkuprawira yang mengatakan bahwa manfaat rotasi kerja antara lain meningkatkan keterampilan karyawan dalam melakukan pekerjaan lebih dari satu tugas. 
Hasil ini sama dengan penelitian Nurdiana (2011) yang menyatakan bahwa rotasi kerja mempunyai pengaruh yang signifikan terhadap kinerja karyawan

Menurut penulis, rotasi yang dilakukan pada perawat di RS Jiwa Dr. Soeharto Heerdjan bermanfaat untuk perawat. Perawat yang bekerja lama di ruang PICU akan memiliki stress yang lebih tinggi dibandingkan perawat yang bekerja bukan di PICU karena penanganan pasien pada kondisi akut lebih susah dibandingkan kondisi pasien yang sudah mulai tenang dan membaik. Stress yang lama dapat berdampak pada penurunan kinerja perawat.

Rotasi perawat dari ruang rawat inap dengan masalah gangguan jiwa ke gangguan fisik bisa melatih kembali keterampilan perawat dalam memasang infuse, selang nasogastrik, kateter, merawat luka yang sudah lama tidak dilakukan menjadi dilakukan kembali juga rotasi ini baik untuk perawat dalam mengingat kembali tentang ilmu patofisiologi.

Dengan rotasi dilakukan, perawat memiliki pengalaman baru dan keterampilan baru dalam menangani pasien-pasien dengan berbagai karakteristik dan berbagai usia sehingga dapat mengurangi kejenuhan Selain itu, perawat mendapat pengalaman baru untuk menangani pasien-pasien gangguan jiwa sehingga hal-hal positif yang didapat dalam penerapan asuhan keperawatan pada satu pasien bisa menjadi pembelajaran bagi perawat untuk menerapkan asuhan keperawatan yang lebih baik kepada pasien lain.

Pada hasil penelitian didapatkan koefisien determinasi, $\mathrm{R} 2=0.606$. hal ini berarti 60,6 $\%$ variasi kinerja diterangkan oleh variabel masa kerja, tingkat pendidikan, dan rotasi kerja; sedangkan sisanya $39.4 \%$ dideterminasi/ditentukan oleh variabelvariabel lain yang tidak dilibatkan dalam penelitian ini. Variabel-variabel lain yang mempengaruhi kinerja perawat adalah imbalan, beban kerja, gaya kepemimpinan, lingkungan kerja, kondisi pasien, pengahargaan, promosi dan sebagainya.

\section{KESIMPULAN}

Berdasarkan hasil analisa data dan pembahasan pada bab terdahulu, maka dapat diambil kesimpulan bahwa masa kerja, tingkat pendidikan dan rotasi kerja memiliki pengaruh sangat signifikan terhadap kinerja karyawan.

Pendidikan dapat meningkatkan kemampuan kognitif, affektif dan psikomotorik seseorang sehingga akan mampu meningkatkan produktivitas kerjanya. Karyawan yang telah bekerja lama memperoleh pengetahuan, wawasan dan keterampilan dalam bekerja yang dapat meningkatkan produktivitas kerjanya.

Hasil penelitian ini sejalan dengan hasil penelitian sebelumnya yang dilakukan oleh Ratna Jaya Diguna pada tahun 2011, yang menyatakan bahwa masa kerja, pendidikan, dan pelatihan berpengaruh signifikan terhadap kinerja karyawan.

Hasil penelitian yang dilakukan oleh Sumarno pada tahun 2007, juga menyatakan bahwa motivasi kerja dan tingkat pendidikan berpengaruh signifikan terhadap kinerja karyawan. Rotasi kerja yang dilakukan kepada perawat berpengaruh signifikan terhadap kinerja.

Penerapan rotasi kerja dapat membangkitkan kembali semangat bekerja dan mengembangkan potensi perawat. Hasil penelitian ini mendukung penelitian yang 
dilakukan oleh Nurdiana pada tahun 2011 menunjukkan bahwa rotasi kerja, kompensasi dan kepuasan kerja berpengaruh signifikan terhadap kinerja karyawan.

Semakin lama masa kerja, semakin tinggi pendidikan dan/atau semakin sering rotasi kerja diperoleh Perawat di RS Jiwa Dr. Soeharto Heerdjan, akan memberikan kinerja perawat yang lebih tinggi. Variabel independen yang paling penting bagi perawat adalah masa kerja kemudian diikuti tingkat pendidikan dan rotasi kerja yang hampir sama pentingnya.

\section{Saran}

Saran untuk Manajemen RS Jiwa Dr. Soeharto Heerdjan

Berdasarkan kesimpulan yang telah diuraikan di atas, penulis memberikan saran sebagai berikut :

Masa kerja, tingkat pendidikan dan rotasi kerja dapat digunakan sebagai rencana dalam pengembangan karir karyawan. Perawat yang memiliki masa kerja lama menujukkan loyalitas kepada rumah sakit. Mengingat loyalitas itu membantu rumah sakit dalam mempertahankan perawat yang unggul dan mengurangi dampak negatif keluar masuknya karyawan (turn over) maka perawat yang memiliki pengalaman yang lama diberi penghargaan, reward, dan kesempatan promosi. Selain itu, pihak manajemen rumah sakit dapat mengadakan program mentoring yang dilakukan perawat senior ke perawat yunior atau manajer perawat memberikan mentoring atau counseling kepada perawat yunior.

Pendidikan merupakan salah satu faktor yang mempengaruhi kinerja perawat dalam melakukan asuhan keperawatan mulai dari pengkajian, analisa data, merumuskan masalah keperawatan dan diagnosa, membuat rencanan asuhan keperawatan, dan melaksanakan asuhan keperawatan hingga evaluasi dan pendokumentasiannya. Oleh karena itu, disarankan agar pihak Manajemen RS Jiwa Dr. Soeharto Heerdjan perlu mengalokasikan anggaran untuk peningkatan kinerja perawat melalui tunjangan pendidikan, dispensasi waktu bekerja untuk kuliah, dan penyediaan bukubuku keperawatan jiwa, psychiatric, majalah kesehatan serta jurnal keperawatan.

Dalam proses perekrutan, pihak manajemen mulai meningkatkan merekrut perawat yang berpendidikan S1 keperawatan dan perawat laki-laki. Selain itu, pihak Manajemen juga memberikan banyak pelatihan kepada perawat-perawat yang terkait dengan penanganan pasien dengan gangguan jiwa untuk meningkatkan kemampuan perawat dalam menangani pasien gangguan jiwa.

Mengingat rotasi kerja mampu membangkitkan kembali semangat bekerja, mengurangi kejenuhan dan meningkatkan keterampilan, penulis menyarankan penerapan rotasi kerja dilakukan pada semua perawat terutama pada perawat yang bekerja di ruang PICU untuk mengurangi stress kerja yang cukup tinggi. Penerapan rotasi kerja memperhatikan karakteristik sebagai berikut :

a. rotasi kerja digunakan untuk meningkatkan keterampilan perawat, memberikan pengalaman kepada perawat yang dibutuhkan dalam posisi manajerial

b. perawat mengerti keterampilan spesifik yang akan dikembangkan dari rotasi

c. semua perawat memiliki peluang yang sama untuk di rotasi tanpa memperhatikan demografi

d. manfaat rotasi kerja dimaksimalkan dan biaya diminimalkan melalui mengatur waktu rotasi untuk mengurangi biaya beban kerja dan membantu perawat mengerti peran dari rotasi kerja dalam perencanaan pengembangan. 
Pada penelitian selanjutnya mungkin dapat dilakukan pengujian terhadap stress kerja, lingkungan kerja, insentif terhadap kinerja perawat di RS Jiwa Dr. Soeharto Heerdjan. Penulis juga merekomendasikan agar dilakukan penelitian tentang rotasi kerja di rumah sakit umum yang kondisi ruangannya dan pasiennya lebih bervariasi daripada di RS Jiwa agar lebih dapat men-generalisasi hasil penelitian.

\section{DAFTAR PUSTAKA}

Aditama, Tjandra, (2007), Manajemen Administrasi Rumah Sakit, Jakarta: UI Press.

Alimul, Azis, (2002), Pengantar Pendidikan Keperawatan, Jakarta: C.V. Sagung Seto.

Bustami, (2011), Penjaminan Mutu Pelayanan Kesehatan dan Akseptabilitasnya, Jakarta: Erlangga.

Depkes, RI, (2008), Petunjuk Pelaksanaan Pengisian Daftar Penilaian Pelaksanaan Pekerjaan Pegawai Departemen Kesehatan, Jakarta.

Dessler, Gary, (2011), Human Resource Management, England: Prentice-Hall, Inc.

Dewit, Susan C, (2009), Fundamental Concepts and Skills for Nursing, St.Louis Missouri: Saunders

Diguna, Ratna J, (2011), Pengaruh Masa Kerja, Pendidikan, dan Pelatihan terhadap Kinerja Karyawan PT. Gajah Tunggal, Tbk, Tesis Magister Manajemen Pasca Sarjana Universitas Esa Unggul, Jakarta.

Gujarati, Damodar N, (2007), Dasar-dasar Ekonometrika, Edisi ke-3, Jakarta: Erlangga.
Homby, Albert S and Wehmeier, Sally, (2005), Oxford Advanced Learner's Dictionary, United Kingdom : Oxford University Press.

Imelda, Mulan M, (2011), Kompetensi Perawat, Kondisi Pasien, dan Kinerja Perawat dalam Penerapan Model Praktek Keperawatan Profesional di RS Jiwa Dr. Soeharto Heerdjan, Tesis Magister Manajemen Pasca Sarjana Universitas Esa Unggul, Jakarta.

Ivancevich, John M, (2010), Human Resource Management, New York: Mc Graw-Hill.

Keliat, Budi A, (2010), Model Praktik Keperawatan Profesional Jiwa, Jakarta: EGC

Kuncoro, Mudrajat, (2009), Metode Riset untuk Bisnis dan Ekonomi, Jakarta: Erlangga.

Lee, Antony, (2011),http://www.health.kompas.com. (diakses tanggal 11 Januari 2011)

Mangkuprawira, Sjafri, (2009), Bisnis, Manajemen, dan Sumberdaya Manusia, Jakarta: Gramedia (2007), Manajemen Mutu Sumber Daya Manusia, Bogor: PT Ghalia Indonesia.

Mansur, Tolkah, (2009), Analisis Pengaruh Budaya Organisasi dan Rotasi Pekerjaan Terhadap Motivasi Kerja untuk meningkatkan Kinerja Pegawai Ditjen Pajak, Tesis Magister Manajemen Pasca Sarjana Universitas Diponegoro, Semarang, http://eprints.undip. ac. id. (Diakses Tanggal 14 januari 2012)

Mathis, Robert L, and Jackson, John H, (2006), Human Resource Management, Terjemahan : Diana Angelica, Jakarta: Penerbit Salemba Empat.

Nurdiana, (2011), Pengaruh Rotasi Kerja, Kompensasi, dan Kepuasan Kerja Terhadap Kinerja Pegawai Sekretariat Daerah Kota Surakarta, Thesis Magister 
Manajemen Pasca Sarjana Universitas Muhammadiyah Surakarta, Surakarta. http ://etd.eprints.ums. ac.id (Diakses Tanggal 14 Januari 2012).

Noe, Raymond A, Hollenbeck, John R, Gerhart, Barry, and Wright, Patrick M, (2006), Human Resource Management, 5th Edition, New York: Mc. Graw-Hill International.

Notoatmodjo, Soekidjo, (2009), Pengembangan $S D M$, Jakarta: Rineka Cipta.

Potter, Patricia A and Perry, Anne G, (2009), Fundamental Keperawatan. Jakarta: EGC.

Rachmawati, Ike K, (2008), Manajemen Sumber Daya Manusia, Yogyakarta: C.V. ANDI OFFSETT.

RS. Jiwa Dr. Soeharto Heerdjan, (2010), Profil Rumah Sakit Jiwa Dr. Soeharto Heerdjan, Jakarta.

Rue, Leslie W and Byars, Lloyd L, (2011), Human Resource Management, New York: Mc. Graw-Hill

Santoso, Singgih, (2011), Mastering SPSS Versi 19.0, Jakarta: Elex Media Komputindo

Sekaran,Uma, (2007), Research Methods For Business. Jakarta: Salemba Empat.

Setiawan \& Kusrini, D, E, (2010), Ekonometrika. Yogyakakarta: Andi.

Sitorus, Ratna, (2006), Model Praktik Keperawatan Profesional, Jakarta: EGC.

Sumarno, (2007), Pengaruh Motivasi kerja dan Tingkat Pendidikan Terhadap Kinerja Pegawai Badan Nasional Penempatan dan Perlindungan Tenaga Kerja Indonesia. Tesis Magister Manajemen Pasca Sarjana Universitas Esa Unggul, Jakarta.

Umar, Husein, (2003), Metode Riset Bisnis, Jakarta: PT. Gramedia Pustaka Utama.
Undang-Undang Republik Indonesia Nomor 20 Tahun 2003 Tentang Sistem Pendidikan Nasional.

Werther, William B and Davis, Keith, (2003), Human Resources Management, New York: Mc. Graw-Hill. 